\title{
一変数および多変数の個人変動範囲による
}

\author{
感度々特異度 \\ ○平木義 雄* 中野 守 雄* 八坂 敏 夫*
}

継続健診の検査成績にみられる個人の生理的変動の様 態は個体によって特有であり，個人の健康動態の把握が 疾病の予防・早期発見に有効であることは，たびたび報 告してきた。これまで, 検査成績の個人の生理的変動巾 を一変数毎に求め, 異常の検出に利用してきたが，今 回，ホメオスタティック・モデルを用い多変数による変 動範囲る検討したので報告する。ホメオスタティック・ モデルでは, セットポイント $\mu$, 時刻 $\mathrm{t} に$ 於ける わりのランダム変動 $\mathrm{e}_{\mathrm{t}}$, 技術䛊差変動 $a_{t}$ により, 実測值 $\mathrm{X}_{\mathrm{t}}$ は, $\mathrm{X}_{\mathrm{t}}=\mu+\mathrm{e}_{\mathrm{t}}+\mathrm{a}_{\mathrm{t}}$ と表わすことができる。多変数 モデルは単変数モデルを一般化すれば得られるが, 一般 に, $\mathrm{p}$ 変数の過去 $\mathrm{t}-1$ 回の平均值ベクトルを $\overline{\mathrm{X}}_{\mathrm{t}-1}$, 分 散共分散行列を $\mathrm{V}_{\mathrm{t}-1}$ と $\mathrm{l}, \mathrm{t}$ 回目の $\mathrm{p}$ 変数の観測值 ベクトルを $\mathrm{X}_{\mathrm{t}}$ とするとき, スカラー量 $\mathrm{M}_{\mathrm{t}}=\left(\mathrm{X}_{\mathrm{t}}\right.$ $\left.\overline{\mathrm{X}}_{\mathrm{t}-1}\right)^{\prime} \mathrm{V}_{\mathrm{t}-1}^{-1}\left(\mathrm{X}_{\mathrm{t}}-\overline{\mathrm{X}}_{\mathrm{t}-1}\right)$ を用いれば, $((\mathrm{t}-1) / \mathrm{t})(\mathrm{t}$ $\mathrm{p}-1) \mathrm{M}_{\mathrm{t}} /(\mathrm{p}(\mathrm{t}-2))$ が自由度 $(\mathrm{p}, \mathrm{t}-\mathrm{p}-1)$ の $\mathrm{F}$ 分布 に従らことから, 異常を判定でさる。ただし（）'は, 転置行列, $V^{-1}{ }_{t-1}$ は逆行列を示す。

対象は, PL 東京健康管理センターで15回以上反復健 診を受けた698名（男性412名，女性286名）で, 受診回 数毎の人数は15回受診者 262 名, 16回204名, 17回211名, 18回21名である。分析項目は, 6 項目で, 多変数モデル では, Ca, T.P., ALB のグループと, LDH, SGOT, ALK. P のグループについて 3 変数モデルを適用した。

検定は，個人について 6 回目以後について行なったの で, 単変数についての 6 項目全てにわたる検定の総数 は，46,014件であり，有意水準 $5 \%$ で有意となった総数 は2,079 (4.5\%) で，6 項目にほぼ平均していた。

また単変数と多変数の変動範囲の関係について調べる と， 3 変数を 1 組とする 2 グループを総合すると, 単変 数での検定で, 3 変数のうち有意な変数が無いセットは のべ, 13,446七ットあり，そのうちの $1.5 \%$ そたる 200
セットは多変数でも有意となった。同様に 3 変数のうち

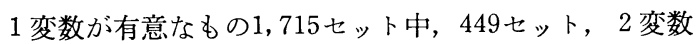

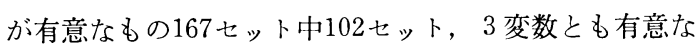

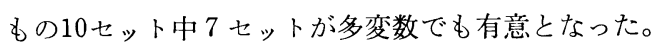

さらに医師により肝疾患と断定された対象について同 様の分析を行なった。この場合，「有意でない」ことを 云うためには診断時と統計的に有意となった期間をスク リーニングする必要があり, その結果, 有意な検查成績 は診断が下される 6 回程度（約 3 年）前までに集中して いることが分った。LDH, SGOT, ALK.P の 3 变数につ いてこの対象にモデルを適用すると，単变数，多変数い づれのモデルでも有意となる人は15名，単変数の及有意 となるのは 9 名, 多变数の及有意 1 名, いづれも有意と ならない人は14名であり,この14名のグループのうち検 査值がもともと高值であった人が13名，また残り 1 名を 含む12名は，検査11回目以前の早い時期に診断が下され 統計的判定の保留されるべき対象であることも分った。 これらを除くと肝疾患者全員について統計的には有意之 なることが分った。

さらに個人について詳細に検討すると，たとえば， AMHTS 検査を16回受診した66歳の男性Aについて, SGOT の変動を見ると，医師による診断が下された 15 回目に集団の正常值上限を初めて越えているが，それ以 前の 9 回目，および14回目に於てすでに，単变数モデル による変動範囲と, 多変数モデル (LDH, SGOT, ALK. $\mathrm{P}$ の 3 変数モデル）での範囲のいら゙れも越え，警告を発 していることが分った。

今回の分析から疾病の early stage をキャッチするた めにこのモデルはかなり有効であると推定できる。さ らに他の検查項目，他の疾病についても詳細に検討を行 ない, 感度, 特異度の向上を計るとともに AMHTS に 於ける診断決定の上に一石を投じたい。

\section{Sensitivity and Specificity by Univariate and Multivariate Subject-Specific Reference Reg- ions}

(PL メディカル・データ・センター) 